\title{
Integrating skills profiling and purchasing portfolio management: An opportunity for building purchasing capability
}

\author{
Louise Knight $^{\mathrm{a}, *}$, Yi-Hsi Tu ${ }^{\mathrm{b}}$, Jude Preston ${ }^{\mathrm{a}}$ \\ a Aston University, Aston Triangle, Birmingham B4 7ET, UK \\ ${ }^{\mathrm{b}}$ Arrow Electronics Taiwan Ltd, 17/F, 150 Jian 1st Road, Zhonghe Dist, New Taipei City, Taipei Country 23511, Taiwan
}

\section{A R T I C L E I N F O}

\section{Article history:}

Received 31 May 2012

Accepted 13 June 2013

Available online 6 July 2013

Keywords:

Purchasing portfolio

Purchasing skill

Cluster analysis

Skill profiling

Procurement HRM

Purchasing competence

\begin{abstract}
A B S T R A C T
Kraljic's (1983) purchasing portfolio approach holds that different types of purchases need different sourcing strategies, underpinned by distinct sets of resources and practices. The approach is widely deployed in business and extensively researched, and yet little research has been conducted on how knowledge and skills vary across a portfolio of purchases. This study extends the body of knowledge on purchasing portfolio management, and its application in the strategic development of purchasing in an organization, and on human resource management in the purchasing function. A novel approach to profiling purchasing skills is proposed, which is well suited to dynamic environments which require flexibility. In a survey, experienced purchasing personnel described a specific purchase and profiled the skills required for effective performance in purchasing that item. Purchases were categorized according to their importance to the organization (internally-oriented evaluation of cost and production factors) and to the supply market (externally-oriented evaluation of commercial risk and uncertainty). Through cluster analysis three key types of purchase situations were identified. The skills required for effective purchasing vary significantly across the three clusters (for 22 skills, $p<0.01$ ). Prior research shows that global organizations use the purchasing portfolio approach to develop sourcing strategies, but also aggregate analyses to inform the design of purchasing arrangements (local vs global) and to develop their improvement plans. Such organizations would also benefit from profiling skills by purchase type. We demonstrate how the survey can be adapted to provide a management tool for global firms seeking to improve procurement capability, flexibility and performance.
\end{abstract}

(c) 2013 Elsevier B.V. All rights reserved.

\section{Introduction}

There is compelling evidence that efficient and effective supply chain management is a key success factor for corporations competing in the global marketplace (Lamming, 1993; Carter and Ellram, 2003; Cousins, 2005; Hartmann et al., 2012), and that the development of purchasing from a tactical to a strategic function can provide sustainable competitive advantage (Ellram and Carr, 1994; Carter and Narasimhan, 1996; Chen et al., 2004). Prior studies examine the relationships between purchasing skills and such variables as strategic purchasing (Carr et al., 2000), supplier integration and supply management performance (Eltantawy et al., 2009), organizational performance (Carr and Smeltzer, 2000; Cousins et al., 2006), and the position of purchasing within the organization (Tassabehji and Moorhouse, 2008).

Though it is not without its critics, the purchasing portfolio approach (Kraljic, 1983; Bensaou, 1999) is widely deployed in

\footnotetext{
* Correspondence to: Engineering Systems and Management, Aston University, Aston Triangle, Birmingham B4 7ET, UK. Tel.: +44 121204 3605; fax: +44 1212043676.

E-mail addresses: 1.knight2@aston.ac.uk (L. Knight),

tuniubou@gmail.com (Y.-H. Tu), prestjac@aston.ac.uk (J. Preston).
}

organizations to improve purchasing performance (Gelderman and van Weele, 2003). It is used to categorize purchases according to a range of internal, product, profit and operational factors and external, supply market conditions - collectively termed 'profit impact' and 'supply risk' factors, respectively (Gelderman and Semeijn, 2006) with the aim of providing different sourcing strategy recommendations for distinctive situations.

Purchasing leaders also focus closely on skills and knowledge requirements and how these vary according to organizational context, where context can be described in terms of corporate strategy, purchasing maturity, organizational structure and business context (Rozemeijer et al., 2003). Globalization, outsourcing and e-commerce are key factors driving rapid and substantial change in the status of purchasing, purchasing job roles and organizational design (Zheng et al., 2007). Various studies point to the reducing importance of what can be regarded as more technical purchasing skills and the growing importance of more generic, 'softer' and more strategic skills (see Zheng et al. (2007) and Eltantawy et al. (2009) for reviews).

The central argument presented in this paper is that those responsible for developing and managing purchasing and supply in complex organizations should profile knowledge and skills 
according to 'purchase type', as defined using a purchasing portfolio approach, to inform organizational design and human resource development within the purchasing function. The case for this is developed from a review of relevant literature - both conceptual and empirical - and from an exploratory study of the relationships between skills and purchase situation. The paper helps to address two research gaps. First, previous studies have profiled skills in various ways, including by job role, by contrasting transactional versus relational purchasing, and by the maturity of the organization. Each approach has advantages, but they do not fit well in highly dynamic and complex settings, as typically applies in global firms. Second, despite the (admittedly brief) mention of the importance of improving purchasing skills in Kraljic's seminal article (Kraljic, 1983, p. 117), little research has been done from a purchasing portfolio perspective to understand better what purchasing skills and knowledge are needed for effective performance in which purchase situations.

Therefore our first aim was to investigate empirically the relative importance of purchasing skills for distinct purchase situations. Do skills requirements vary significantly according to profit impact and supply risk, and if so how? To achieve this it was necessary: (1) to categorize purchase types; (2) to identify a set of purchasing skills; (3) to develop a skill profile for each purchase type (4) to compare and contrast these profiles. The second, broader aim was to examine critically the profiling process itself and its relevance to practice, and to propose how it might be applied to support functional development.

For the survey, variables on four dimensions were deployed to describe purchasing situations (product characteristics, product cost and value, supply market and attributes of the current, main supplier), and a set of 33 purchasing skills was compiled. Using the exploratory technique of cluster analysis (Aldenderfer and Blashfield, 1984), three distinct types of purchase types were identified: strategic $(n=27)$, tactical $(n=32)$ and routine $(n=13)$. The skill profiles for each cluster show important variation (for 22 skills, $p<0.01)$. The detailed results are reported below.

The review of literature on purchasing people's skills and knowledge (referred to hereafter as 'skills', for brevity) and their management reveals a focus on higher level skills needed among staff working in an increasingly strategic function. Little consideration is paid to skills needed for local and/or more operational purchasing. Further, though articles on skills examine their impact on performance and on intermediary factors such as function status and supplier integration (Eltantawy et al., 2009), they offer little in terms of insights on the organizational design implications of their results. On the other hand, purchasing portfolio management literature addresses the technique's use in strategic (i.e. mature) purchasing functions in complex organizations. Though the implications for organizational design are discussed (Trautmann et al., 2009b) and for personnel are recognized (Quintens et al., 2006), we found no literature which explores the relationships in any detail. In the purchasing literature, at least, if not in practice, there is a missing link: skills profiling is not connected to portfolio management, despite the prevalence of both in research and practice. This points to a key gap, and an opportunity to develop knowledge and techniques to support the design and development of complex, dynamic purchasing organizations. Here we explain how the approach used in the survey may be adapted and used by managers and for further research.

The paper is organized as follows. The next section is a two part literature review focusing on skills, considering first skills profiling from a technical HRM perspective and then skills research on purchasing and supply. Section 3 is in two parts reviewing literature on the purchasing portfolio approach, and the organization of global sourcing, focusing particularly on applying the portfolio approach to the design and management of global purchasing. The methodology for the exploratory survey is set out in Section 4, followed by the results. In Section 6 results are discussed in the context of academic research, and in terms of implications for practice. Finally, conclusions are presented.

\section{Literature review on skills profiling}

\subsection{Competence and skill profiling}

Traditional job analysis (Brannick et al., 2007) sought to define the prerequisite technical skills and knowledge necessary for successful execution of the role, including 'soft' skills such as team-working or effective communication. More recently, competency profiling (Campion et al., 2011) is also commonly carried out during the job analysis process. Although the two terms are often used interchangeably, a competence is different from a skill in that 'competence' refers to the behaviorally-demonstrated use of technical skills and knowledge, and competence profiling is intended to focus on competences distinctly associated with superior performance (Bartram, 2005). Competency analysis is important for a range of HRM activities, including "creating and updating job descriptions; recruiting and selecting employees; designing and evaluating training and career education; developing incentive and reward systems; creating succession plans" (Gayeski et al., 2007).

In practice, the HRM task of role profiling includes both skill and competence elements, analyzing and describing the specific or technical knowledge or skills necessary to execute the tasks required, as well as the innate or acquired abilities and other individual characteristics critical to overall performance (Dierdorff and Morgeson, 2007). For the purpose of this work, we focus on the specific technical, and industry, knowledge and skills necessary for efficacy in purchasing roles, rather than more generic, behavioral competencies.

Job skills analysis and competency profiling both involve the use of similar techniques, and are therefore subject to many of the same limitations and criticisms. These are important considerations if the outcomes of the process are to be both valid and legally defensible as part of an organization's HRM practice (Dierdorff and Morgeson, 2007). The process of identifying the knowledge, skills, attributes and other characteristics that differentiate superior performance typically involves current job-holders or their line managers, working with HR experts, and possibly informed by external research. The process is time-consuming and resource intensive. The outcome may be highly subjective (Sanchez and Levine, 2009; Dierdorff and Morgeson, 2009). The capacity and ability of functional specialists to contribute to this process may be limited (Dierdorff and Wilson, 2003; Jones et al., 2001). The viability or the validity, or both, of the process can be a significant problem. Furthermore, the process focuses on past and present HR requirements, rather than future needs. Traditional methods 'describe and measure the status quo' (Hayton and McEvoy, 2006) rather than defining the critical requirements for future performance, to align with the business context and strategic objectives of the organization (Campion et al., 2011), and supporting the development of the function to become more strategic (e.g. Long and Ismail, 2012).

In summary, job analysis and competence and skill profiling are problematic because: most profiling techniques are highly resource intensive; they are typically retrospective rather than future focused; skills frameworks can be regarded as highly subjective and thus gain little buy-in from key stakeholders; they fail to convincingly link skills with performance. By their very nature, profiling and applying skills frameworks risks the reduction of diversity and creativity. All these challenges are exacerbated for large, complex organizations operating globally, and facing high levels of diversity and uncertainty, and rapid change. 


\subsection{Purchasing knowledge and skills}

Despite being recognized as an important theme for the development of the function (Zheng et al., 2007), human resource management and development of purchasing people has received relatively little attention in purchasing and supply academic research, and almost none from HRM studies. The article by Mulder et al. (2005) is a rare exception, reporting on a research program for course development for professional training, involving job profiling complemented by trends analysis. The article includes extensive reflection on the profiling process and concludes that "small-scale, context-related analyses of jobs adds most value, but that is not sufficient for ensuring faith [i.e. validity] in the study results... using a mix of in-depth and large-scale methods is recommended in conducting job profile research".

Large-scale, quantitative studies dominate research conducted by purchasing experts and published in purchasing and supply journals. Researchers use various data sources taking, for example, the perspective of purchasing professionals (e.g. Kolchin and Giunipero, 1993; Murphy, 1995; Carr and Smeltzer, 2000; Giunipero et al., 2006), or that of recruiters or employers (e.g. Down and Liedtka, 1994; Pooley and Dunn, 1994; Cruz and Murphy, 1996). The resulting taxonomies of purchasing skills show considerable overlap, including for example, influencing and persuasion skills (e.g. Kolchin and Giunipero, 1993; Giunipero and Pearcy, 2000; Giunipero et al., 2005) and ability to work in teams (e.g. Carr and Smeltzer, 2000; Giunipero and Pearcy, 2000; Tassabehji and Moorhouse, 2008) as key skills for purchasing executives. Several skills are widely recognized as critical for professional purchasers; for example, negotiation skills (e.g. Kolchin and Giunipero, 1993; Pooley and Dunn, 1994; Murphy, 1995), computer literacy (e.g. Kolchin and Giunipero, 1993; Murphy, 1995; Giunipero and Flint, 2001), and product knowledge (e.g. Cavinato, 1987; Killen and Kamauff, 1995). Several studies highlight particular skills not raised by others. For instance, Giunipero and Handfield (2004) found considerable concern over ethical behavior.

Several studies provide evidence of evolving skill profiles (Faes et al., 2001; Tassabehji and Moorhouse, 2008; Giunipero et al., 2006). Business environment dynamics and the changing role of procurement/supply chain department are driving these changes in the skills needed for effective performance at the level of the purchasing function (Freeman and Cavinato, 1992; Giunipero and Pearcy, 2000; Cousins and Spekman, 2003; Giunipero et al., 2006; Cousins et al., 2006). Other research shows that skillful and knowledgeable buyers are a prerequisite for a strategic-oriented purchasing function (Pearson and Gritzmacher, 1990; Carr and Smeltzer, 2000). Among those focusing on a strategic purchasing perspective, Giunipero and Handfield (2004) and Giunipero et al. (2006) observe that the supply management functions are composed of two distinct classifications of purchasing personnel, namely strategic purchasers and transactional buyers, each with distinct skills. Management must accommodate the development of dissimilar sets of skills for these two groups.

Cousins et al. (2006) examined different typologies of purchasing functions and found that 'strategic purchasers' (one of the identified configurations) who possess sophisticated purchasing skills and are highly recognized by top management, tend to outperform other configurations in regard to supplier integration, supplier relationship performance, production outcomes, and financial performance. Reinecke et al. (2007) showed that people-related resources and practices explained variation in purchasing and corporate financial performance, whereas the purchasing systems and technologies did not.

Most research concentrates on observing the changes in key sets of purchasing skills (e.g. Giunipero and Handfield, 2004; Giunipero et al., 2006), developing taxonomies of purchasing skills (e.g. Giunipero and Pearcy, 2000; Tassabehji and Moorhouse, 2008), or examining purchasing skills using such factors as organizational performance (e.g. Cousins et al., 2006) or strategic purchasing (e.g. Carr et al., 2000).

Work on purchasing and supply management skills has been criticized for being predominantly exploratory, focusing on identifying and categorizing skills (Eltantawy et al., 2009, p. 927); very little research addresses skills development (cf Mulder et al., 2005; Feisel et al., 2011). There are no significant linkages to theoretical foundations, reflecting the state of this aspect of HRM generally. It is also notable that HRM-related literature within the field of purchasing and supply is rather tightly bounded, and risks becoming selfreferential. Nevertheless, research using extensive lists of skills to explore similarities and differences between roles and settings, and over time, continues. These large-scale methods are practical and effective in terms of resource - a key factor for academic researchers and purchasing function leaders alike. We thus conclude that, approached with caution, the skills profiling approach has merit, enabling comparison within large and diverse organizations, between organizations, and between sectors. We note however that, despite the extensive use in practice and research of the purchasing portfolio approach (discussed below), little consideration is paid to the possible link between purchase type and purchasing skills.

\section{The management and application of purchasing portfolios in a global purchasing context}

\subsection{Product classification and purchasing portfolio models}

According to Kraljic (1983, p. 112-5), the portfolio approach includes four key phases, namely product classification, supply market analysis, determination of strategic supply position, and

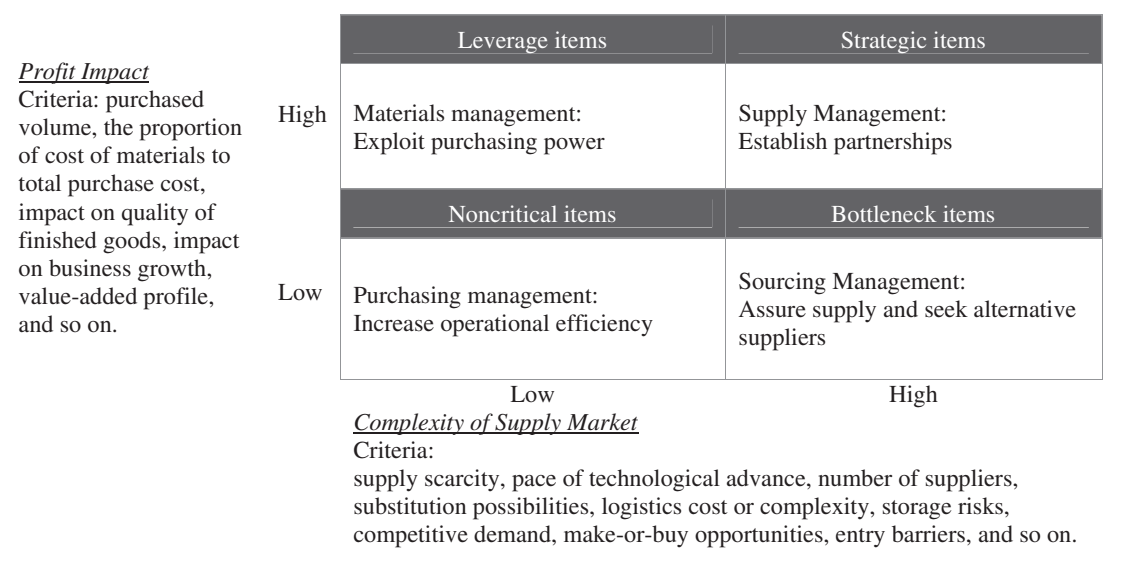

Fig. 1. The Kraljic matrix (modified from Kraljic, 1983, p. 111). 
development of strategies. The Kraljic matrix (see Fig. 1) classifies purchases against two dimensions. The external dimension concerns the factors regarding suppliers and supply market, while the internal dimension relates to the importance and profit impact of a given product (Dubois and Pedersen, 2002). Each dimension needs to be assessed against a number of variables. There are several variants to the Kraljic matrix, usually focusing on the factors and variables for the two dimension (e.g. Olsen and Ellram, 1997; Lilliecreutz and Ydreskog, 1999; Padhi et al., 2012), but none differ significantly from the initial conceptualization (Gelderman and van Weele, 2005). The resulting four types of purchase situations can be differentiated by characteristics including typical time horizons for contracts and relationships, key performance criteria and decision authority, to align with the four distinctive strategies shown in Fig. 1.

The practical application of the Kraljic matrix exceeds its original design. For example, practitioners utilize the Kraljic portfolio model not only to position products and formulate purchasing strategies but also to shift products within the matrix by, for example, encouraging new market entrants so moving an item from strategic to leverage status, and to set goals for sourcing improvements (Gelderman and van Weele, 2002, 2005).

Bensaou's portfolio model (Bensaou, 1999) focuses on business relations. By comparing buyer and supplier level of (tangible and intangible) investments, relationships are classified into four types: market exchange, captive buyer, captive supplier, and strategic partnership, and for each type a typical contextual profile was identified covering product, market and supplier characteristics (see Fig. 2). By comparing high and low performing relationships, Bensaou (1999) also profiled management practices associated with high performance for each quadrant.

There are several important criticisms of the purchasing portfolio approach. It disregards the supplier side (Lilliecreutz and Ydreskog, 1999; Kamann, 2000) and fails to provide suggestions for proactively changing the existing power dependence (Cox, 1997; Gelderman and van Weele, 2002). Nellore and Soderquist (2000) doubt whether the variables used in the portfolio models are the most appropriate ones. Measurement of dimensions and variables is also viewed as a major weakness (Olsen and Ellram, 1997) and lacking rigor. Padhi et al. (2012) argue for less subjective methods for positioning purchases on the matrix. Furthermore, the approach does not take account of interdependencies between products (Olsen and Ellram, 1997; Ritter, 2000) and between agent relationships (Dubois and Pedersen, 2002). Pagell et al. (2010) found that, motivated by sustainability objectives, companies were adopting purchasing practices more often associated with strategic suppliers (i.e. longer term, for collaborative relations) for acquisitions most appropriately classified as 'leverage'. Nevertheless, even among these critics, there is wide consensus that the purchasing portfolio approach provides useful tools for describing and differentiating purchasing situations and developing appropriate sourcing strategies.

\subsection{The organization of global purchasing}

How best to organize purchasing activities is a key aspect of purchasing and supply management (PSM) for large, multi-site organizations in all sectors. Scholars of public procurement and global sourcing investigate various facets of how to both meet local needs and achieve purchasing synergies - the benefits arising "from any form of co-operation between two or more business units belonging to the same corporation" less the additional costs of coordination between units (Rozemeijer et al., 2003, p. 5). Coordinating purchasing across business units can deliver economies of scale, or economies of information and learning, or economies of process (Trautmann et al., 2009a), and is positively associated with purchasing performance (Rozemeijer et al., 2003, p. 5).

Supported by evidence from a survey of 264 Belgian companies, Quintens et al. (2006) develop a construct for global purchasing strategy with two key dimensions, the configuration of purchasing (i.e. the extent of decentralization) and the standardization of purchasing, in three aspects - purchasing process; product; purchasing personnel. "The dimensions capture two important dualities in today's globalizing business: (a) standardize procedures, products and personnel or adapt to plant-, country- or product

Market Exchange Low buyer's specific investments/ Low supplier's specific investments

Product Characteristics: Standardised products; mature technology; little innovation; low engineering efforts required

Market Characteristics: Stable or declining market; highly competitive market; many capable suppliers Supplier Characteristics: Small shops; low switching cost; low bargaining power; strong economic reliance on buying firms

on Captive Buyer High buyer's specific investments/ Low supplier's specific investments

Product Characteristics: Technically complex; mature and well-understood technology; little improvements

Market Characteristics: Limited market growth; concentrated market; buyers have an internal manufacturing capacity

Supplier Characteristics: Proprietary technology; few established players; strong bargaining power; buyers heavily depend on suppliers' skills

Captive Supplier Low buyer's specific investments/ High supplier's specific investments

Product Characteristics: New technology developed by suppliers; frequent innovations; significant engineering efforts required

Market Characteristics: High growth market; fierce competition; few qualified players; unstable market

Supplier Characteristics: Strong proprietary technology; strong financial capabilities and research and development skills; low bargaining power; heavy dependence on the buying firm

Strategic Partnership High buyer's specific investments/ High supplier's specific investments

Product Characteristics: High level of customisation; mutual adjustments required; new technology; frequent design changes; strong engineering expertise required

Market Characteristics: High growth market; highly competitive and concentrated market; lack of dominant design

Supplier Characteristics: Strong proprietary technology; strong skills and capabilities in design,

engineering, and manufacturing

Fig. 2. Bensaou's contextual profiles (Bensaou, 1999, p. 38). 
category specific circumstances and (b) centralize activities or decentralize them" (Quintens et al., 2006, p. 889).

Following a resource based view, Quintens et al. (2006) assert that firms which successfully align purchasing product, process and personnel policies can achieve competitive advantage (see Fig. 3). This approach contrasts with Trautmann et al. (2009b) who, adopting an information-processing (IP) view, propose that global sourcing effectiveness is a function of the fit between the uncertainty facing sub-units (IP requirements) and integration mechanisms, which constitute IP capacity. Here, centralization and standardization are aspects of vertical integration. Firms can also deploy lateral integration mechanisms, such as job rotation and cross-unit teams (see Fig. 4). Based on comparative case study analysis of 12 categories of purchases sourced globally (three multinational firms $\mathrm{x} 4$ product types [raw materials; CAPEX; services; MRO]), Trautmann et al. (2009b) identified three product groups according to the primary motive for global sourcing (seeking economies of (a) scale (b) innovation and learning (c) process), and profiled the associated uncertainty faced by the organization and integration mechanisms. In an article based on research within an MNC, Trautmann et al. (2009a) provide a detailed method for evaluating which products are suitable for global sourcing according to the type of economies being sought.

Trautmann et al.'s (2009a, 2009b) work provides advice on which products should be sourced on a global basis and for what synergies, and how units should coordinate, but is silent on the implications for purchasing personnel. Whilst Quintens et al, (2006) are explicit in arguing for careful development of international purchasing staff, they are not specific about how this might be done, nor about the particular skills and knowledge requirements for global purchasing. Successful management of purchasing in global firms is not however just a matter of organizing internationally coordinated business but also supporting the development of local purchasing, and managing the interface

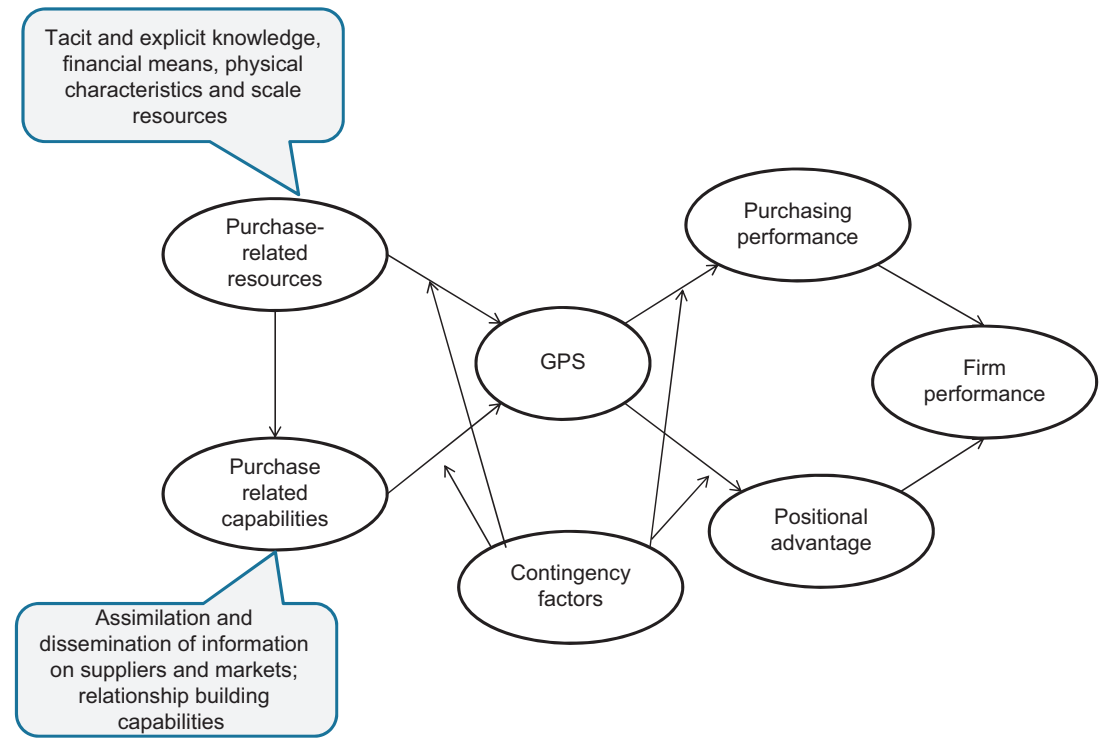

Fig. 3. Global purchasing strategy conceptual framework.

Source: Quintens et al, 2006 (call out boxes added).

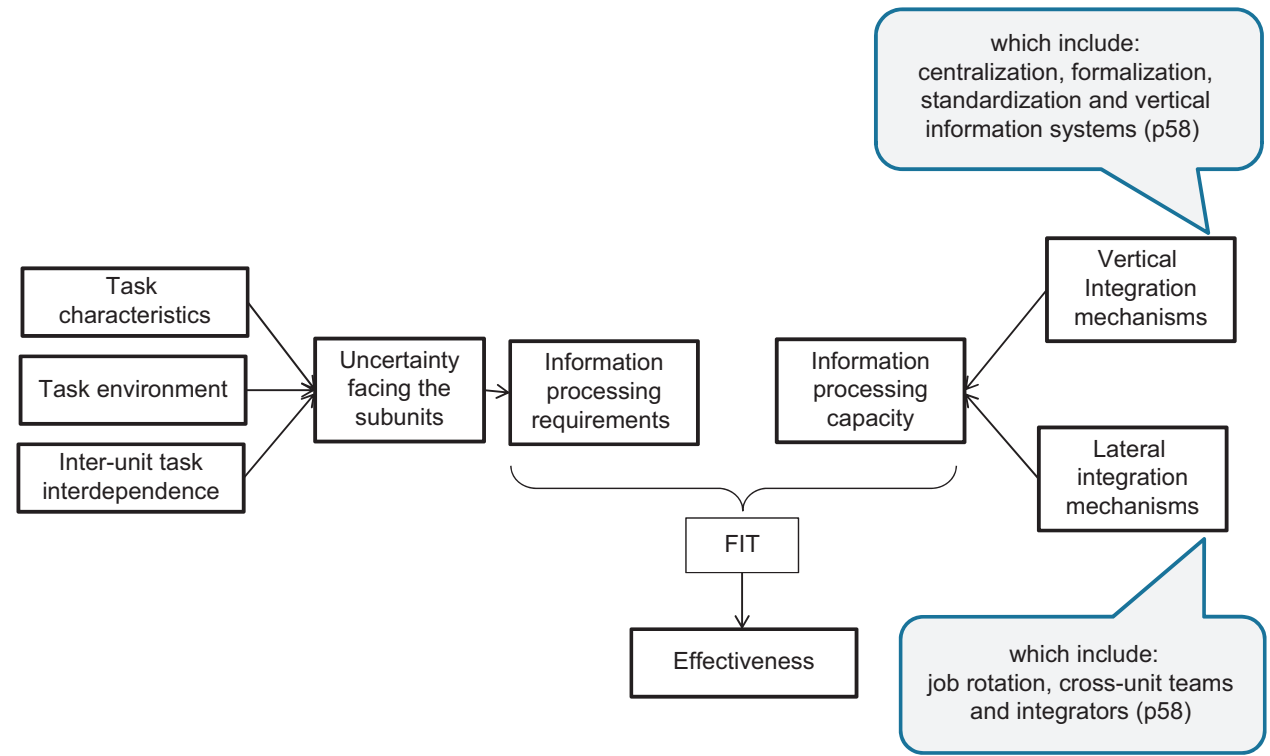

Fig. 4. The general information processing framework.

Source: Trautmans et al (2009b), adapted from Tushman and Nadler (1978) ( Call out boxes added). 
between local and global sourcing teams across geographical and business unit boundaries.

There is an argument for the need for skills flexibility, on both individual levels and within sourcing teams (Driedonks et al., 2010), to safeguard the supply of operation-critical inputs against potential disruptions. This is particularly pertinent with increased globalization of communications and transportation, which whilst potentially providing cost-economies also carry increased risk of supply interruption from natural, political and economic crises. This skills agility is critical given the pace of change within the increasingly globalized purchasing environment. Frequent supply disruptions require rapid shifts in sourcing strategies (Shao, 2011) and, potentially, rapid adjustments to purchasing arrangements and redistribution of responsibilities between people and sites.

The insights from the literature suggest that there is an opportunity for developing purchasing management practice through explicitly coordinating purchasing portfolio management and skill profiling, and that focusing skills profiling just on formal job roles would be too limiting. If instead, for the purposes of organizational design and development issues, we regard purchasing agents as responsible for a portfolio of purchases, then we can conduct finer-grained analyses. In a stable setting, it would still make sense to map skills requirements onto jobs, and allocate purchasing responsibilities to those jobs. But in other circumstances the fixed point of job roles would be too constraining, for example: in situations where rapid adjustments are needed; in organizations where there is wide variety in personnel management practices; where managers want to explore options for alternative designs or re-organization. But this only holds if we can in fact have confidence that skills requirements do vary according to profit impact and supply market factors. This is what we sought to test in the empirical work described next.

\section{Research design and methods}

To assess whether and, if so, how skills vary by purchasing type (categorized according to internal and supply market factors) we sought a design which could be exploratory, could formally test the proposition that skills do vary by purchase type, and which could provide results which are meaningful and readily applied to practice. Prior research provided various lists of dimensions for categorizing purchase types and lists of purchasing knowledge and skills; we wanted to build on this work but make no assumptions about their relationships. Cluster analysis (Aldenderfer and Blashfield, 1984) met all these objectives, allowing the inductive identification of categories of purchase types.

Cluster analysis groups items into comparatively homogeneous subsets (Aldenderfer and Blashfield, 1984). Whereas factor analysis (Gorsuch, 1983) classifies variables into factors, cluster analysis categorizes observations or cases into groups (Blaikie, 2003). Moreover, in factor analysis variables may be grouped into more than one factor, whereas in cluster analysis, a case can only be assigned to one cluster (Bailey, 1994; Krishnaswamy et al., 2006). Given that the purpose of this stage was to group products (i.e. observations) rather than characteristics (i.e. variables) and that the products were not allowed to belong to more than one group, cluster analysis was preferable to factor analysis. To classify products, this study followed a two-step clustering methodology (Punj and Stewart, 1983). The first step was a hierarchical approach, while the second step applied a non-hierarchical clustering method.

For the first step, Punj and Stewart (1983) specifically point out that two agglomerative techniques (i.e. average linkage and Ward's minimum variance method) could be adopted to determine an appropriate number of clusters. After considering their tendencies

Table 1

Purchase situation profile, by cluster.

\begin{tabular}{|c|c|c|c|c|c|c|c|c|c|}
\hline \multirow[t]{2}{*}{ Four-point Likert scale with $1=$ strongly disagree and $4=$ strongly agree } & & \multicolumn{2}{|c|}{$\begin{array}{l}\text { Cluster } 1 \\
n=27\end{array}$} & \multicolumn{2}{|c|}{$\begin{array}{l}\text { Cluster } 2 \\
n=32\end{array}$} & \multicolumn{2}{|c|}{$\begin{array}{l}\text { Cluster } 3 \\
n=13\end{array}$} & \multicolumn{2}{|c|}{ Total $n=72$} \\
\hline & & Mean & $\begin{array}{l}\text { Std. } \\
\text { Dev }\end{array}$ & Mean & $\begin{array}{l}\text { Std. } \\
\text { Dev }\end{array}$ & Mean & $\begin{array}{l}\text { Std. } \\
\text { Dev }\end{array}$ & Mean & $\begin{array}{l}\text { Std. } \\
\text { Dev }\end{array}$ \\
\hline The product has significant impact on the quality of finished goods. & PP1 & 3.78 & 0.42 & 3.00 & 0.95 & 1.77 & 1.01 & 3.07 & 1.07 \\
\hline The technology necessary for the product evolves rapidly. & PP2 & 3.04 & 0.90 & 2.53 & 0.98 & 1.46 & 0.88 & 2.53 & 1.07 \\
\hline Your corporation requires high level of customisation. & PP3 & 3.26 & 0.76 & 2.84 & 0.99 & 1.62 & 0.96 & 2.78 & 1.06 \\
\hline Frequent design changes happen to the product. & PP4 & 3.15 & 1.10 & 2.50 & 1.05 & 1.15 & 0.55 & 2.50 & 1.21 \\
\hline The possibility of product substitution is limited. & PP5 & 2.52 & 0.94 & 2.22 & 0.87 & 1.38 & 0.51 & 2.18 & 0.92 \\
\hline $\begin{array}{l}\text { The product requires tight mutual adjustments (i.e. supplier and your company) in key } \\
\text { processes. }\end{array}$ & PP6 & 3.74 & 0.45 & 3.19 & 0.82 & 1.62 & 1.04 & 3.11 & 1.06 \\
\hline Product Profile MEAN & PPmean & 3.25 & 0.35 & 2.71 & 0.46 & 1.50 & 0.52 & 2.69 & 0.75 \\
\hline The product has significant impact on profitability. & PCP1 & 3.70 & 0.54 & 2.72 & 0.77 & 1.54 & 0.66 & 2.88 & 1.02 \\
\hline Cost of the product is a high proportion of total purchase cost. & PCP2 & 3.74 & 0.45 & 2.59 & 0.91 & 2.00 & 0.82 & 2.92 & 1.00 \\
\hline The logistics cost regarding transportation of the product is very high. & РCP3 & 3.11 & 0.75 & 2.25 & 0.84 & 1.38 & 0.51 & 2.42 & 0.98 \\
\hline The storage risk of the product is significant. & PCP4 & 3.37 & 0.74 & 2.38 & 0.91 & 1.38 & 0.77 & 2.57 & 1.09 \\
\hline Product Cost Profile MEAN & PCPmean & 3.48 & 0.43 & 2.48 & 0.51 & 1.58 & 0.54 & 2.69 & 0.85 \\
\hline The supply market is highly competitive. & SMP1 & 3.41 & 0.57 & 3.31 & 0.69 & 3.69 & 0.63 & 3.42 & 0.65 \\
\hline There are a large number of capable suppliers. & SMP2 & 2.96 & 0.90 & 3.19 & 0.69 & 3.69 & 0.48 & 3.19 & 0.78 \\
\hline The switching cost is very low. & SMP3 & 2.15 & 1.06 & 2.31 & 0.59 & 3.31 & 0.95 & 2.43 & 0.95 \\
\hline Supply Market Profile MEAN & SMPmean & 2.84 & 0.58 & 2.94 & 0.48 & 3.56 & 0.52 & 3.01 & 0.58 \\
\hline The current main supplier has proprietary technology to manufacture the product. & SP1 & 3.30 & 0.82 & 2.28 & 0.92 & 3.08 & 1.04 & 2.81 & 1.02 \\
\hline The current main supplier has recognized skills and capabilities in R\&D. & SP2 & 3.56 & 0.58 & 2.72 & 0.89 & 3.00 & 1.08 & 3.08 & 0.90 \\
\hline $\begin{array}{l}\text { The current main supplier has recognized skills and capabilities in engineering and } \\
\text { manufacturing. }\end{array}$ & SP3 & 3.59 & 0.57 & 3.03 & 0.78 & 3.62 & 0.65 & 3.35 & 0.73 \\
\hline The current main supplier has strong bargaining power. & SP4 & 3.19 & 0.68 & 2.84 & 0.72 & 2.85 & 0.80 & 2.97 & 0.73 \\
\hline The current main supplier has little economic reliance on your company. & SP5 & 2.52 & 0.75 & 2.63 & 0.79 & 2.69 & 1.03 & 2.60 & 0.82 \\
\hline Supplier Profile MEAN & SPmean & 3.23 & 0.33 & 2.70 & 0.47 & 3.05 & 0.77 & 2.96 & 0.54 \\
\hline
\end{tabular}


to categorize objects and the type of variables utilized in this research (Ketchen and Shook, 1996), Ward's method was selected.

Based on the seminal work of Kraljic (1983) and the highlycited work of Bensaou (1999), 18 variables were identified to describe purchasing dimensions (see Table 1). The 10 internallyoriented dimensions (often known 'profit impact' variables) consisted of four describing aspects of the products' costs, and the balance related to more technical aspects such as customization, impact on quality and rate of development. Of the 8 externallyoriented dimensions (often known as 'supply risk' variables), five related to the status of the relationship with the current main supplier, and three to the supply market generally.

The list of purchasing skills was developed by synthesizing the skills presented in four articles (Giunipero and Pearcy, 2000; Carr and Smeltzer, 2000; Giunipero et al., 2006; Tassabehji and Moorhouse, 2008). All these were relatively recent and were targeted at purchasing professionals rather than, say, recruitment managers. They differ however in the techniques used, which include questionnaires, focus groups and interviews. This produced a list of 33 purchasing related skills. Whereas Giunipero and Pearcy (2000) and Tassabehji and Moorhouse (2008) sought to develop skills categories, this was not necessary in this work since the individual skill was the unit of analysis.

The survey instrument was designed to capture data on the relative importance of purchasing-related skills for a specific purchase. It was designed to be completed by purchasing agents on the basis that it is they, rather than their managers, who can best identify the key skills needed in their daily work. To concentrate on successful performance, respondents were required to have more than 2 years' experience and were asked to select and describe "one product which you are highly confident that you can purchase effectively", referred to as the 'focal' product.

The survey was administered online to the target group of experienced purchasing personnel ( $>2$ years in the profession) in large or medium sized corporations in Taiwan, by emailing a random sample of 600 companies from the Ministry of Economic Affairs database. An email reminder was distributed to the entire sample, since responses were anonymous.

Despite its comparatively small population and territory, in terms of economic outcomes, Taiwan has outperformed most others countries. It is well-known for its information and hardware industry; for example, it is one of the top three producers of IT hardware (Datamonitor, 2010). Chow et al. (2008) conducted a survey in both US and Taiwan to analyze the relationships between the components of supply chain management and a firm's performance and found comparable results between organizations in Taiwan and the US in terms of a positive effect of superior supply-chain competencies on organizational performance. Carr et al. (2000) indicated that purchasing plays a vital role in Asian corporations since acquiring quality and low cost raw materials in a timely way can contribute considerably to the performance of these organizations. On the other hand, given that labor costs in China are lower than that in Taiwan, a large number of Taiwanese companies have either contracted out some laborintensive works to Chinese firms or established their own factories in China. Consequently, the complexity and importance of purchasing and supply management have risen significantly in recent years. The effectiveness of purchasing can have greater impact on Taiwanese organizations' performance than ever before, making Taiwan an interesting context for investigating purchasing.

Respondents described the features of the focal purchase using the 18 dimensions listed in Table 1 and a 4 point Likert scale $(1=$ strongly disagree to $4=$ strongly agree). Then they indicated the importance of each of 33 skills for effective purchasing of the identified product, on a four point Likert scale $(1=$ extremely unimportant and $4=$ extremely important). There were three reasons for selecting four point Likert scales: the reliability of scales which have no middle categories seems to be higher than that of scales with midpoints (Weems and Onwuegbuzie, 2001); removing the midpoint helps to reduce social desirability bias (Garland, 1991); the midpoint response bias would be minimized by providing a scale with an even number of categories (Baumgartner and Steenkamp, 2006), which can be particularly important as East Asian respondents tend to use the midpoint of a Likert scale (Stening and Everett, 1984; Chen et al., 1995; Lee et al., 2002).

Seventy-seven responses were received, of which 5 were excluded due to missing data. The $12 \%$ response rate was comparable to that achieved in Carr et al. (2000)'s questionnaire survey in Taiwan. Responses for demographic variables are shown in Fig. 5.

Cluster analysis groups items into comparatively homogeneous subsets (Aldenderfer and Blashfield, 1984; Blaikie, 2003). A two-step clustering methodology (Punj and Stewart, 1983) based on product, product cost, supply market, and main supplier data provided a three cluster solution. The clusters were named to reflect the key characteristics of the purchasing type they represent (see Table 1) and descriptive profiles produced for purchase type and skills (see Table 2). Key similarities and differences between skills profiles were analyzed, across the three clusters (Kruskal-Wallis $\mathrm{H}$ test) and with pairs of clusters (Mann-Whitney U test) (Bryman and Cramer, 2011). Further details on the analytical process are provided in the following presentation of findings.
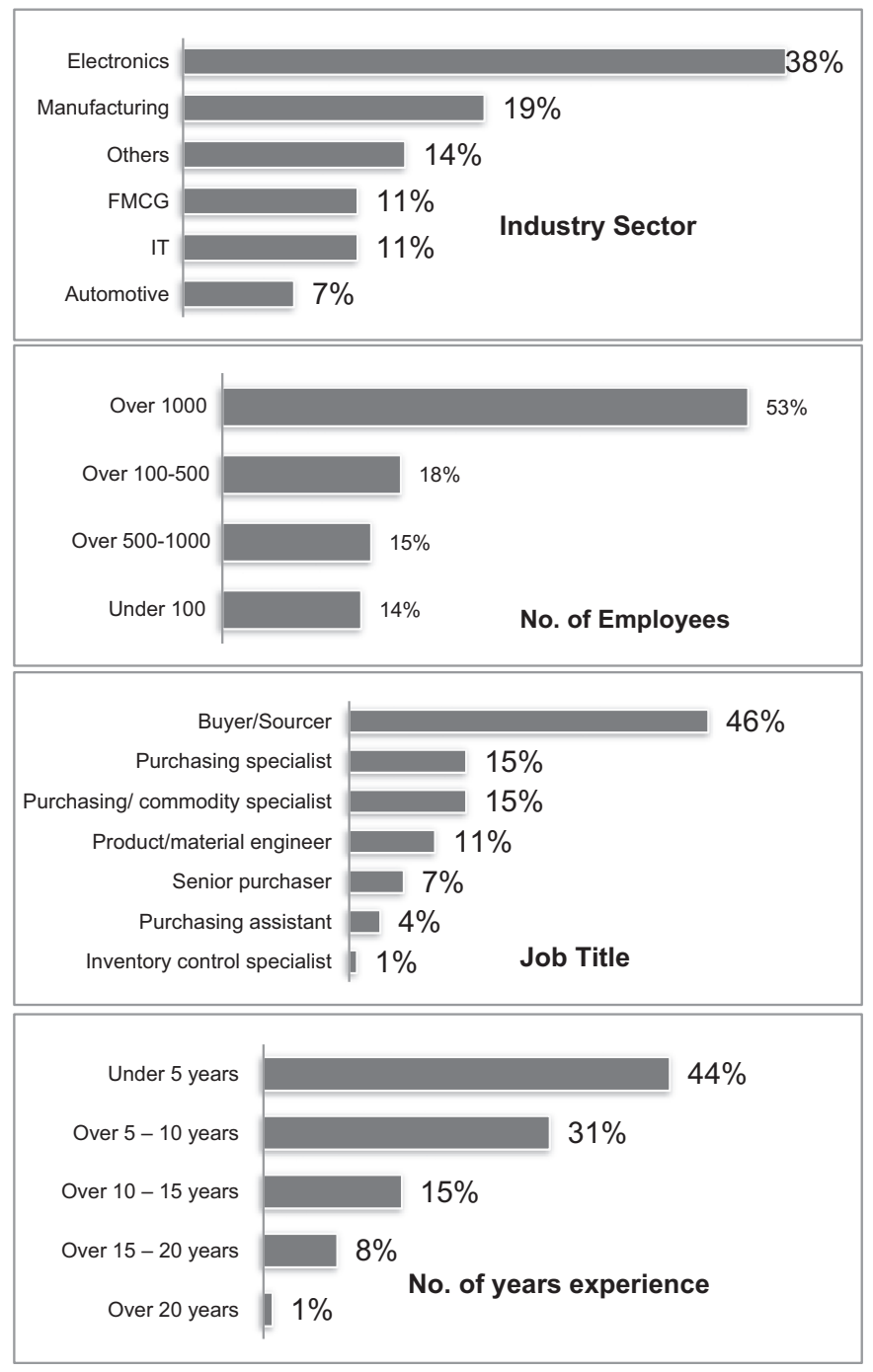

Fig. 5. Respondents' demographics $(n=72)$. 


\section{Survey results}

\subsection{Cluster 1: strategic purchase type}

'Strategic purchase', the first cluster $(n=27)$, includes products such as printed circuit boards, chipsets, chemical vapor depositors, and components for power panels. With the highest scores on all context dimensions, this purchase type not only has significant impact on quality and profitability but also requires high level of mutual adjustment between the buying firm and its main supplier. The supplier tends to possess proprietary technology and/or strong capabilities and skills in R\&D and innovation.

'Coordinating skills' was the highest ranked item, with 22 more skills being considered 'important' or 'extremely important'. The top 5 ranked skills are Communication skills [PS1]; Negotiation skills [PS2]; Influencing and persuasion [PS3]; Problem-solving skills [PS5]; Coordinating skills [PS6]. Skills such as specification development and understanding manufacturing terminology and process are relatively important for the strategic purchase type. This may be the result of high levels of customization, continual design changes, and frequent innovations. Also, the need for mutual adjustments in turn necessitates teamwork and managing internal customers skills. Responses show the importance of decision-making, strategic thinking, and forecasting skills. Furthermore, it is notable that decision-making skills, strategic thinking, managing internal customers, and ability to work in teams are key skills which, in contrast, do not feature in the top 20 ranked skills for either Tactical or Routine purchase types.
The strategic purchase profile fits well with the supply management quadrant of Kraljic matrix (1983) and the strategic partnership quadrant of Bensaou model (1999). The supply strategy recommended for Kraljic's strategic quadrant is to aim to achieve a balance of power based on long-term collaborative arrangements. Nevertheless, the skill of managing strategic partnerships is ranked only 21st. A possible reason for this is, although cooperation and collaboration do exist between the buying company and its main supplier building a formal long-term buyer-supplier relationship could be an uncommon approach adopted by firms operating in Taiwan.

\subsection{Cluster 2: tactical purchase type}

The 'tactical purchase' cluster $(n=32)$ includes products such as cable, power cords, heat sinks, alcoholic beverages, UV glue, car glass, passive components, and electronic switches. It has moderate mean values for product, product cost, and supply market profile, while the mean for supplier profile is the lowest. Compared to the Strategic cluster, cases in the Tactical purchase cluster are associated with a lower level of customization, less frequent design changes, and lower proportion of purchasing-related cost. The Tactical purchase type has more potential suppliers and lower switching costs than Strategic purchases. Furthermore, the lowest mean (2.70) suggests that their current main suppliers have certain economic reliance on the buying firm and their bargaining power is comparatively weak.

Communication skills are ranked first. In all, 15 skills are considered to be 'important' or 'extremely important'. The top five skills are identical to the top 5 for strategic purchases [PS1, 2, 3, 5, 6]. The

Table 2

Skills profile by cluster.

\begin{tabular}{|c|c|c|c|c|c|c|c|c|c|c|}
\hline \multicolumn{2}{|c|}{ Purchasing Skills } & \multicolumn{2}{|c|}{ Whole sample } & \multicolumn{2}{|c|}{ Cluster 1 Strategic } & \multicolumn{2}{|c|}{ Cluster 2 Tactical } & \multicolumn{2}{|c|}{ Cluster 3 Routine } & \multirow[t]{2}{*}{ Stat. Sig.* } \\
\hline PS & Name of skills & Rank & Mean & Rank & Mean & Rank & Mean & Rank & Mean & \\
\hline 1 & Communication skills & 1 & 3.65 & 3 & 3.63 & 1 & 3.66 & 1 & 3.69 & - \\
\hline 2 & Negotiation skills & 3 & 3.5 & 3 & 3.63 & 2 & 3.50 & 3 & 3.23 & - \\
\hline 3 & Influencing and persuasion & 2 & 3.56 & 2 & 3.74 & 3 & 3.44 & 2 & 3.46 & - \\
\hline 4 & Decision-making skills & 20 & 2.67 & 14 & 3.30 & 23 & 2.72 & 28 & 1.23 & +++ \\
\hline 5 & Problem-solving skills & 6 & 3.26 & 5 & 3.59 & 5 & 3.28 & 10 & 2.54 & +++ \\
\hline 6 & Coordinating skills & 4 & 3.42 & 1 & 3.78 & 5 & 3.28 & 6 & 3.00 & ++ \\
\hline 7 & Conflict resolution & 13 & 2.97 & 11 & 3.33 & 12 & 3.06 & 17 & 2.00 & ++ \\
\hline 8 & Ability to work in teams & 26 & 2.56 & 18 & 3.19 & 28 & 2.56 & 28 & 1.23 & +++ \\
\hline 9 & Leadership & 33 & 2.22 & 29 & 2.78 & 33 & 2.25 & 32 & 1.00 & +++ \\
\hline 10 & Managing internal customers & 24 & 2.63 & 17 & 3.26 & 26 & 2.63 & 27 & 1.31 & +++ \\
\hline 11 & Customer focus & 28 & 2.5 & 27 & 2.85 & 25 & 2.66 & 26 & 1.38 & +++ \\
\hline 12 & Project management & 31 & 2.38 & 24 & 2.96 & 29 & 2.44 & 32 & 1.00 & +++ \\
\hline 13 & Change management & 12 & 3 & 11 & 3.33 & 16 & 2.97 & 12 & 2.38 & + \\
\hline 14 & Strategic thinking & 27 & 2.51 & 14 & 3.30 & 31 & 2.41 & 30 & 1.15 & +++ \\
\hline 15 & Computer literacy & 29 & 2.44 & 33 & 2.11 & 24 & 2.69 & 10 & 2.54 & - \\
\hline 16 & Analytical skills & 16 & 2.83 & 23 & 3.00 & 12 & 3.06 & 18 & 1.92 & ++ \\
\hline 17 & Mathematical skills & 25 & 2.57 & 32 & 2.63 & 27 & 2.59 & 12 & 2.38 & - \\
\hline 18 & Blueprint reading & 30 & 2.43 & 24 & 2.96 & 32 & 2.38 & 24 & 1.46 & +++ \\
\hline 19 & Technical writing & 32 & 2.33 & 29 & 2.78 & 29 & 2.44 & 30 & 1.15 & +++ \\
\hline 20 & Product knowledge & 5 & 3.33 & 5 & 3.59 & 4 & 3.41 & 9 & 2.62 & +++ \\
\hline 21 & Specification development & 10 & 3.06 & 7 & 3.48 & 12 & 3.06 & 16 & 2.15 & ++ \\
\hline 22 & Understanding manuf. terminology & 17 & 2.82 & 10 & 3.41 & 19 & 2.81 & 20 & 1.62 & +++ \\
\hline 23 & Understanding manuf. process & 18 & 2.78 & 11 & 3.33 & 19 & 2.81 & 23 & 1.54 & +++ \\
\hline 24 & Forecasting skills & 8 & 3.21 & 7 & 3.48 & 15 & 3.00 & 4 & 3.15 & - \\
\hline 25 & Cost analysis & 11 & 3.01 & 20 & 3.11 & 9 & 3.22 & 14 & 2.31 & ++ \\
\hline 26 & Quality management & 20 & 2.67 & 29 & 2.78 & 22 & 2.75 & 15 & 2.23 & - \\
\hline 27 & Supplier evaluation & 13 & 2.97 & 27 & 2.85 & 10 & 3.13 & 7 & 2.85 & - \\
\hline 28 & Supplier cost targeting & 9 & 3.18 & 19 & 3.15 & 8 & 3.25 & 5 & 3.08 & - \\
\hline 29 & Understanding business conditions & 15 & 2.96 & 14 & 3.30 & 10 & 3.13 & 19 & 1.85 & +++ \\
\hline 30 & Supplier relationship management & 7 & 3.25 & 7 & 3.48 & 5 & 3.28 & 8 & 2.69 & + \\
\hline 31 & Supply base research & 20 & 2.67 & 26 & 2.93 & 17 & 2.88 & 20 & 1.62 & +++ \\
\hline 32 & Managing strategic partnerships & 23 & 2.64 & 21 & 3.04 & 21 & 2.78 & 24 & 1.46 & +++ \\
\hline 33 & Risk management & 19 & 2.71 & 21 & 3.04 & 17 & 2.88 & 20 & 1.62 & +++ \\
\hline
\end{tabular}

Key: “-”= not significant $(p>0.05)$; “+”=significant $(p<0.05) ; “++$ " =highly significant $(p<0.01)$; “+ + +"=very highly significant $(p<0.001)$.

Four-point Likert scale with $1=$ extremely unimportant and $4=$ extremely important. 
Tactical purchase profile fits well with Kraljic's (1983) 'leverage item' in several respects: they both have high impact on both business growth and the quality of final goods; their cost of purchasing is a high proportion of total purchase cost; there are many capable suppliers and substitution is possible. Furthermore, their supply markets are characterized by relatively low switching cost and the bargaining power of the suppliers tends to be weak. However, the profile indicates some degree of customization, mutual adjustment and design changes, which do not feature in Kralijc's profile.

\subsection{Cluster 3: routine product type}

Routine purchase $(n=13)$ is the third cluster, with products such as MRO items and screws - standardized items which account for a low proportion of purchase cost. The Routine cluster profile maps well to Kraljic's (1983) non-critical items and to the market exchange quadrant of Bensaou model (1999). Suppliers have good skills and capabilities in engineering and manufacturing and have only limited economic reliance on the buying company (in contrast to Bensaou's model). They also have low impact on quality of final goods, rely on mature technology, and there is a high possibility of substitution. Moreover, the product cost profile is characterized by low purchase and logistics costs, low storage risk, and little impact on profitability. The supply market is highly competitive.

Only 5 purchasing skills are ranked as very important or important [PS 1, 2, 3, PS24 forecasting skills and PS28 supplier cost targeting], indeed only 11 skills exceed the mid-point on the scale of 2.5 .

\subsection{Differences between clusters.}

It is notable that for all three clusters PS1, PS2 and PS3 were highly ranked. The profile of skills by purchase type cluster (Table 2) shows statistically significant differences between clusters for $24(p<0.05)$ of the 33 skills. This makes a strong case for the value of this approach.

A scattergram of the average scores for the internal (PP+PCP) and external (SP+SMP reverse coded) dimensions for profiling a purchase situation shows the increasing risk and complexity across the three clusters (Fig. 6). As these rise, so does the number of required skills classified as 'important' or 'extremely important' (i.e. mean equal or exceeds 3: CL3 $n=6$ skills; CL2 $n=15$ skills; CL1 =n 23 skills).

Visual inspection of the profiles for purchase type dimensions and skills profiles revealed much clearer distinctions between clusters 1 and 3, and between clusters 2 and 3, than between clusters 1 and 2 (strategic and tactical). To make better sense of this we reviewed the variation between clusters on a pairwise basis (following Zhang et al., 2008), comparing the statistical significance of differences between pairs of purchase type clusters and for the 33 skills.

This confirmed that many skills which are significantly different across all 3 clusters, are not so between clusters 1 and 2 . Similarly, the pattern of statistically significant differences varies across the four purchase type dimensions between cluster pairs. For example the three pairs of clusters are clearly differentiated by product cost profile variables, but supplier profile variables only differentiate clusters 1 and 2, and supply market profiles only differentiate clusters 1 and 3. (Further details of this second round analysis are available from the corresponding author). We carefully considered the implications of these observations, and tested the dataset for unusual cases but SPSS results revealed this was not significant.

Furthermore, for each pair of clusters we identified which skills were significantly different between pairs of clusters and compared the relative importance of the skills to the clusters. Tables 3a-3c show the results of this analysis, taking the mid-point of the importance scale (2.5) to define the quadrants and showing in brackets the difference between the mean scores for each skill. This analysis

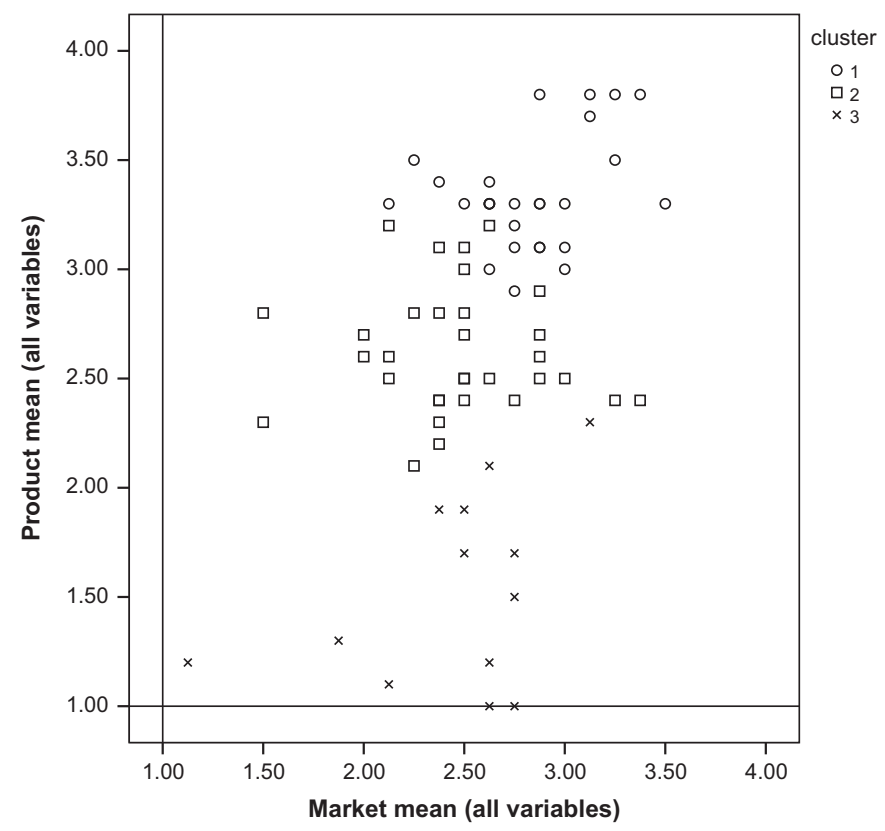

Fig. 6. Comparing cases by cluster, by mean of all product related variables and mean of all market related variables (supply market variables reverse coded).

confirms the findings of the visual inspection. Ten of the 12 skills which differ significantly between Strategic and Tactical purchase types are important to both, and the greatest difference between their mean importance is 0.89 . In contrast, 24 skills are significantly different between the Tactical and Routine clusters, and between the Strategic and Routine clusters, though only 4 and 2 skills respectively are considered important for both of the clusters being compared. Rather than discount the overall approach to our study, these later results suggest that pairwise comparisons are valuable, since they indicate which variables provide a stronger base for explaining the clusters in narrative form - narratives that are needed for making use of the data in practice to plan the development of the purchasing function.

Our analysis also suggests that care is needed in explaining apparent similarities. For example, forecasting is a vital skill (i.e. ranked in top 10) for both Strategic products and Routine products, but the likely reasons differ. High storage risk, rapid evolution of required technology, and frequent design changes could necessitate accurate forecast of future demand for Strategic products, while consolidating purchases to gain economies of scale and reducing administrative cost would lead to the application of forecasting skill when managing Routine products.

\section{Discussion}

\subsection{How skills requirements vary by purchase type - variation and measurement}

Much of the recent research on purchasing skills has, appropriately, been aimed at understanding what skills are needed to raise the performance and profile of the purchasing function to be more strategic (e.g. Giunipero and Handfield, 2004; Giunipero et al., 2006; Tassabehji and Moorhouse, 2008). Other studies focus instead on the changing skills needs for buyers (e.g. Faes et al., 2001) as perceived by business leaders without explicitly addressing the status and contribution of the purchasing function. These studies are important for the long term development of the function and the profession but, we would argue, are not sufficient. This inquiry follows a different logic, profiling skills against 
Table 3a

Comparing skills for clusters 1 and 2 (in brackets: mean for cluster 1 minus mean for cluster 2).

$\begin{array}{ll}\text { High } & \text { PS18 Blueprint } \\ \text { importance } & \text { reading }(0.58)\end{array}$

Cluster 1

Low

Low importance

$(<2.5)$
PS3 Influencing and persuasion (0.3)

PS4 Decision-making skills (0.58)

PS6 Coordinating skills (0.5)

PS8 Ability to work in teams (0.63)

PS10 Managing internal customers (0.63)

PS13 Change management (0.36)

PS14 Strategic thinking (0.89)

PS21 Specification development (0.42)

PS22 Understanding manuf. terminology (0.6)

PS23 Understanding manuf. process (0.52)

PS15 Computer literacy $(-0.58)$

High importance

$(\geq 2.5)$

Cluster 2

Table 3b

Comparing skills for clusters 1 and 3 (in brackets: mean for cluster 1 minus mean for cluster 3 ).

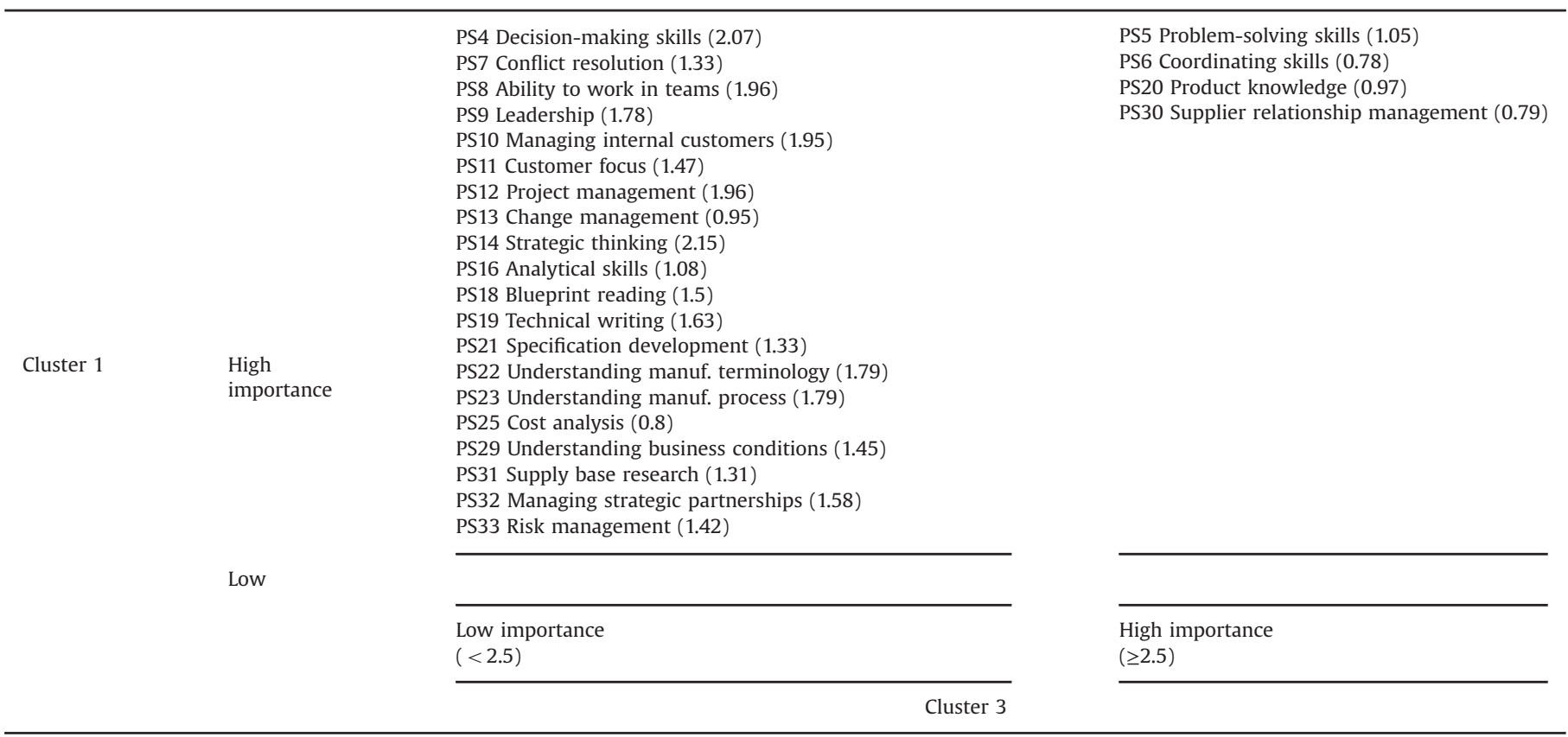

Table 3c

Comparing skills for clusters 2 and 3 (in brackets: mean for cluster 2 minus mean for cluster 3 ).

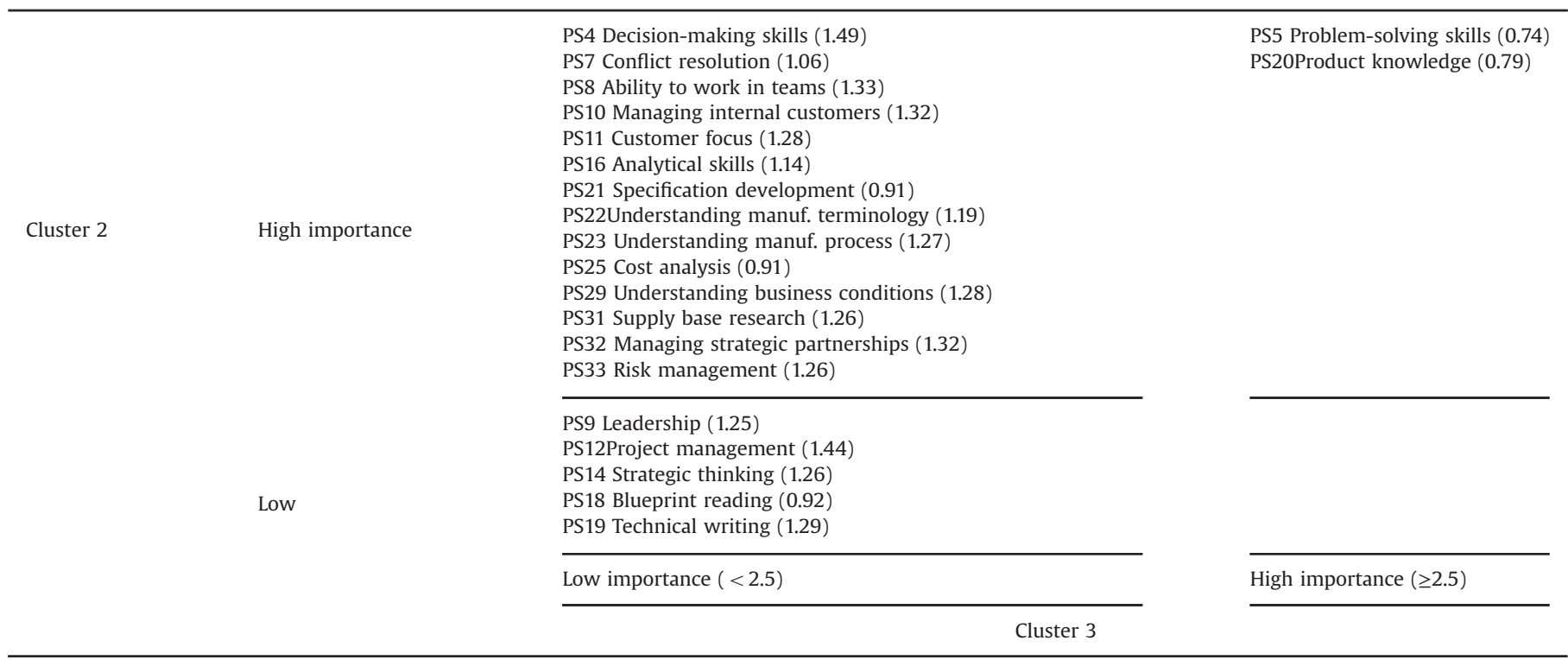


types of purchases. To identify purchase type, rather than assume the fit of Kralijc or Bensaou's categorizations of purchasing situations, we adopted a more grounded, exploratory approach and, using cluster analysis, identified three clusters of cases.

The results show clear variation of skills profile by cluster. As market risk and complexity, and product importance, rise, we observe both an increase in the number of skills considered important and their rising relative importance. Pairwise analysis of the skills profiles for the clusters provides a finer-grained analysis, indicating a pathway for building skills, tracking from cluster 3 , via cluster 2 to cluster 1 .

There are several important limitations to the survey process. Respondents were not guided about what constitutes purchasing (bounding the role/process) or what constitutes effective performance. These were the result of choices made in the trade-off between detail and length in the survey; we favored brevity to encourage higher response rates. Similarly, more detail can be provided to define the skills. Further, the results for communication, negotiation and influencing and persuasion (PS1, PS2, PS3) suggest that these variables require refinement.

Four sets of variables were identified from prior research to describe and categorize purchase situations. These variables proved useful and adequate for this study. Nevertheless, the results notably the pairwise comparison of significant differences between clusters - point to future improvements. In our sample, product related dimensions were more important differentiators of clusters than market related dimensions. If this were replicated in a wider survey, case study research could help explain this and refine market related dimensions. With a much larger sample, factor analysis could be deployed to address these issues, both for purchase types and purchasing skill variables.

\subsection{Discussion: implications for purchasing management}

Whereas from a research point of view a larger-scale survey would be interesting, a practice perspective on the implications of this literature review and empirical study raises the question of how best to make use of the approach in specific organizations. Our focus was on large, complex organizations operating in dynamic environments. The assumption underlying the discussion below is that such firms may well already have in place some form of purchasing portfolio management, or some form of profiling of skills for purchasing professionals, or both. This leads to four related proposals, all advocating a survey to profile skills by purchase type, but with data collection, sampling and analysis strategies adapted to fit existing firm practices. These variable features of the proposed survey are presented in Table 4.

In summary, in a company setting, an adapted survey and carefully designed sampling plan could: extend the description of the focal product purchase to include evaluation of purchase performance (why the respondent considers this to have been a successful purchase); target a specific mix of purchases, for representativeness across the firms' full range of purchases (preselecting the purchases for which skills are evaluated); target respondents considered to be high performers to mitigate the impact of the subjective evaluation of success.

By adopting the relevant approach outlined above, a firm would both leverage established policies and processes and be able to undertake competency analysis, thereby generating and synthesizing large data sets efficiently and effectively (Gayeski et al., 2007). Purchasing leaders could also test their established policies and

Table 4

Adapting the survey for various firm contexts: steps prior to profiling skills by purchase type.

\begin{tabular}{|c|c|c|c|}
\hline & & \multicolumn{2}{|l|}{ Firm has established purchasing portfolio management framework? } \\
\hline & & YES & NO \\
\hline $\begin{array}{l}\text { Firm has skills profiling } \\
\text { approach specific to } \\
\text { the purchasing } \\
\text { function? }\end{array}$ & YES & $\begin{array}{l}\text { Using the established compilation of purchasing skills and the } \\
\text { established dimensions for positioning products on the } \\
\text { portfolio matrix } \\
\text { Using a structured sample of respondents of personnel from across } \\
\text { the organization who are recognized as consistently high } \\
\text { performers, and focal purchases which map across all categories of } \\
\text { purchase situations }\end{array}$ & $\begin{array}{l}\text { First deriving a set of internally-oriented and externally-oriented } \\
\text { dimensions for describing purchase situations from literature and } \\
\text { from exploratory analysis of purchases across multiple sites } \\
\text { Using the established compilation of purchasing skills and the } \\
\text { novel list of portfolio dimensions } \\
\text { Targeting the survey to access wide range of purchase situations. } \\
\text { Care would be needed with the design of the sampling strategy } \\
\text { achieve variety but also: to maintain the focus on superior } \\
\text { performance }{ }^{\mathrm{a}} \text {; to avoid leading respondents in their choice of focal } \\
\text { product. } \\
\text { Assuming sufficient responses, use factor analysis to evaluate the } \\
\text { dimension sets } \\
\text { Use cluster analysis techniques to identify a typology of purchase } \\
\text { situations }\end{array}$ \\
\hline & NO & $\begin{array}{l}\text { Using the established dimensions for positioning products on the } \\
\text { portfolio matrix, and targeting responses to provide a balanced } \\
\text { dataset representing all types of purchases } \\
\text { Using a list of purchasing skills and knowledge from literature and } \\
\text { from, say, interviews with selected purchasing agents and } \\
\text { managers in the firm } \\
\text { Whilst clustering by purchase type is not relevant here, factor } \\
\text { analysis could be used to refine the skills lists and profiles. }\end{array}$ & $\begin{array}{l}\text { Deriving a set of internally-oriented and externally-oriented } \\
\text { dimensions for describing purchase situations from literature and } \\
\text { from exploratory analysis of purchases across multiple sites } \\
\text { Deriving a list of purchasing skills and knowledge from literature } \\
\text { and from, say, interviews with selected purchasing agents and } \\
\text { managers in the firm } \\
\text { Targeting the survey to access wide range of purchase situations. } \\
\text { Care would be needed with the design of the sampling strategy } \\
\text { achieve variety but also: to maintain the focus on superior } \\
\text { performance }{ }^{\text {a }} \text { to avoid leading respondents in their choice of focal } \\
\text { product. } \\
\text { Assuming sufficient responses, use factor analysis to evaluate the } \\
\text { construct validity of dimension sets }{ }^{\mathrm{b}} \\
\text { Use cluster analysis techniques to identify a typology of purchase } \\
\text { situations }\end{array}$ \\
\hline
\end{tabular}

\footnotetext{
a Operationalized here by asking experienced personnel to answer questions on a product "which you are highly confident that you can purchase effectively".

${ }^{\mathrm{b}}$ Operationalized here as product, product cost, main supplier and supply market.
} 
processes, for example using factor analysis to validate established purchase situation dimensions.

We suggest that organizations which can effectively integrate purchasing portfolio management and skills profiling would gain more than just better HRM practices (Gayeski et al., 2007), valuable as these are. Global company armed with robust data on

1) purchases mapped against a typology based on the purchasing portfolio approach;

2) responsibility for purchases mapped against purchasing personnel (individuals or teams);

3) skills requirements profiled by type of purchasing situation;

4) skills availability, i.e. current competence of purchasing personnel within the organization.

\section{would be very well equipped for}

- determining the design of the purchasing function (centralized, coordinated, or locally determined purchasing);

- implementing integration mechanisms, especially horizontal mechanisms such as job rotation;

- designing development programs for business units, teams and individual personnel;

- responding to internally motivated or externally driven changes which require rapid reconfiguration of resources;

- and planning the strategic development of the function.

The approach addresses the methodological challenges of competency analysis (Gayeski et al., 2007), and offers a mechanism for improving alignment and promoting flexibility (Shub and Stonebraker, 2009), both of which are antecedents of higher levels of purchasing performance in global organizations.

\section{Conclusion}

This exploratory investigation of how purchasing skills vary by purchase type has yielded new insights into the purchasing portfolio approach and on what skills are important for effective performance in different settings. It also provides a novel approach to skill profiling which has considerable potential for supporting strategic and operational management of the purchasing function in global firms. It provides objective, quantifiable evidence, and yet is not highly resource intensive.

Compared to skills profiling centered on job role, the approach developed here leverages the well-established purchasing portfolio approach to link explicitly purchasing practices and strategies with personnel's purchasing responsibilities and skills. It is not driven by legacies found in organizational structure or job design, nor in implicit values and assumptions about what makes a good purchaser. It adapts not only to the needs of those in high-profile, more strategic roles but to purchasing personnel across the firm. Furthermore, the approach revolves around the commercial characteristics of a product type, rather than its technical properties or the industry sector. Thus it can accommodate high levels of diversity - in products and people, and organizational - as found in companies operating across national and cultural boundaries.

Though the survey results are not surprising, they are interesting. The clusters map well onto established categorizations, offering strong empirical support for the portfolio approach. The results provide a skills profile for each cluster with high levels of confidence in the key differences and good face validity in the resulting descriptive profiles. The major contribution of this work, however, lies in the design of the study which draws on the knowledge of 'front-line' staff and provides a novel way of linking skills to context, in a way which builds on and significantly extends prior research. Further research with a broader target population is recommended to generate a tool that could be deployed by purchasing leaders and HRM professionals to develop the procurement function and its personnel.

\section{References}

Aldenderfer, M.S., Blashfield, R.K., 1984. Cluster Analysis. Sage Publications, California.

Bailey, K.D. 1994. Typologies and Taxonomies: An Introduction to Classification Techniques. Sage Publications, California.

Bartram, D., 2005. The great eight competencies: a criterion-centric approach to validation. Journal of Applied Psychology 90, 1185-1203.

Baumgartner, H., Steenkamp, J., 2006. Response biases in marketing research. In: Grover, R., Vriens, M. (Eds.), The Handbook of Marketing Research: Uses, Misuses, and Future Advances. Sage Publications, California, pp. 204-236.

Bensaou, M., 1999. Portfolios of buyer-supplier relationships. Sloan Management Review 40. (35-44)

Blaikie, N., 2003. Analysing Quantitative Data: From Description to Explanation. Sage Publications, London.

Brannick, M.T., Levine, E.L., Morgeson, F.P., 2007. Job Analysis: Methods, Research and Applications for Human Resource Management, 2nd ed.. Sage Publications, Thousand Oaks, CA.

Bryman, A., Cramer, D., 2011. Quantitative Data Analysis with SPSS 17, 18 \& 19. A Guide for Social Scientists. Routledge, London.

Campion, M.A., Fink, A., Ruggerberg, B.J., Carr, L., Phillips, G.M., Odman, R.B., 2011 Doing competencies well: best practices in competency modelling. Personnel Psychology 64, 225-262.

Carr, A.S., Leong, G.K., Sheu, C., 2000. A study of purchasing practices in Taiwan. International Journal of Operations \& Production Management 20, 1427-1445.

Carr, A.S., Smeltzer, L.R., 2000. An empirical study of the relationships among purchasing skills and strategic purchasing, financial performance, and supplier responsiveness. Journal of Supply Chain Management 36, 40-54.

Carter, C.R., Ellram, L.M., 2003. Thirty-five years of the journal of supply chain management: where have we been and where are we going? Journal of Supply Chain Management 39, 27-39.

Carter, C.R., Narasimhan, R., 1996. Is purchasing really strategic? International Journal of Purchasing \& Materials Management 32, 20-28.

Cavinato, J., 1987. The purchasing skills you need, Distribution, pp. 42-43.

Chen, C., Lee, S.Y., Stevenson, H.W., 1995. Response style and cross-cultural comparisons of rating scales among east Asian and North American students. Psychological Science 6, 170-175.

Chen, I.J., Paulraj, A., Lado, A.A., 2004. Strategic purchasing, supply management, and firm performance. Journal of Operations Management 22, 505-523.

Chow, W.S., Madu, C.N., Kuei, C.-H., Lu, M.H., Lin, C., Tseng, H., 2008. Supply chain management in the US and Taiwan: an empirical study. Omega-International Journal of Management Science 36, 665-679.

Cousins, P.D., 2005. The alignment of appropriate firm and supply strategies for competitive advantage. International Journal of Operations \& Production Management 25, 403-428.

Cousins, P.D., Lawson, B., Squire, B., 2006. An empirical taxonomy of purchasing functions. International Journal of Operations \& Production Management 26 775-794

Cousins, P.D., Spekman, R., 2003. Strategic supply and the management of interand intra-organisational relationships. Journal of Purchasing and Supply Management 9, 19-29.

Cox, A., 1997. Business Success - A Way of Thinking About Stategy, Critical Supply Chain Assets and Operational Best Practice. Earlsgate Press, UK.

Cruz, C., Murphy, E., 1996. Purchasing's new importance requires a broader education, Purchasing, pp. 46-49.

Datamonitor, 2010. Country Analysis Report - Taiwan: In-depth PESTLE Insights.

Dierdorff, E.C., Morgeson, F.P., 2007. Consensus in work role requirements: the influence of discrete occupational context on role expectations. Journal of Applied Psychology 92, 1228-1241.

Dierdorff, E.C., Morgeson, F.P., 2009. Effects of descriptor specificity and observability on incumbent work analysis ratings. Personnel Psychology 62, 601-628.

Dierdorff, E.C., Wilson, M.A., 2003. A meta-analysis of job analysis reliability. Journal of Applied Psychology 88, 635-646.

Down, K., Liedtka, J., 1994. What corporations seek in MBA hires, Selections, pp. 34-39.

Driedonks, B.A., Gevers, J.M.P., Van Weele, A.J., 2010. Managing sourcing team effectiveness: the need for a team perspective in purchasing organizations. Journal of Purchasing and Supply Management 16, 109-117.

Dubois, A., Pedersen, A.C., 2002. Why relationships do not fit into purchasing portfolio models - a comparison between the portfolio and industrial network approaches. European Journal of Purchasing \& Supply Management 8, 35-42.

Ellram, L.M., Carr, A.S., 1994. Stategic purchasing: a history and review of the literature. Journal of Supply Chain Logistics 30, 9-19.

Eltantawy, R.A., Giunipero, L., Fox, G.L., 2009. A strategic skill based model of supplier integration and its effect on supply management performance. Industrial Marketing Management 38, 925-936. 
Faes, W., Knight, L., Matthyssens, P., 2001. Buyer profiles: an empirical investigation of changing organisational requirements. European Journal of Purchasing \& Supply Management 7, 197-208.

Feisel, E., Hartmann, E., Giunipero, L., 2011. The importance of the human aspect in the supply function: Strategies for developing PSM proficiency. Journal of Purchasing and Supply Management 17 (1), 54-67.

Freeman, V.T., Cavinato, J.L., 1992. Fostering strategic change in a function through executive education: the case of purchasing. Journal of Management Development 11, 25-30.

Garland, R., 1991. The mid-point on a rating scale: is it desirable? Marketing Bulletin 2, 66-70.

Gayeski, D.M., Golden, T.P., Andrade, S., Mason, H., 2007. Bringing competency analysis into the 21st century. Performance Improvement 46, 9-16.

Gelderman, C.J., van Weele, A.J., 2003. Handling measurement issues and strategic directions in Kraljic's purchasing portfolio model. Journal of Purchasing \& Supply Management 9 (5), 207-216.

Gelderman, C.J., Semeijn, J., 2006. Managing the global supply base through purchasing portfolio management. Journal of Purchasing and Supply Management 12, 209-217.

Gelderman, C.J., van Weele, A.J., 2002. Strategic direction through purchasing portfolio management: a case study. Journal of Supply Chain Management 38, 30-37.

Gelderman, C.J., van Weele, A.J., 2005. Purchasing portfolio models: a critique and update. Journal of Supply Chain Management 41, 19-28.

Giunipero, L., Handfield, R.B., Eltantawy, R., 2006. Supply management's evolution: key skill sets for the supply manager of the future. International Journal of Operations \& Production Management 26, 822-844.

Giunipero, L.C., Denslow, D., Eltantawy, R., 2005. Purchasing/supply chain management flexibility. Moving to an Entrepreneurial Skill Set Industrial Marketing Management 34, 602-613.

Giunipero, L.C., Flint, D.J., 2001. Purchasing practices in Saudi Arabia - an exploratory analysis. International Journal of Physical Distribution \& Logistics Management 31, 686-704.

Giunipero, L.C., Handfield, R.B., 2004. Purchasing Education and Training II.

Giunipero, L.C., Pearcy, D.H., 2000. World-class purchasing skills: an empirical investigation. Journal of Supply Chain Management 36 (4), 4-13.

Gorsuch, R.L., 1983. Factor Analysis, 2nd ed.. Lawrence Erlbaum Associates, New Jersey.

Hartmann, E., Kerkfeld, D., Henke, M., 2012. Top and bottom line relevance of purchasing and supply management. Journal of Purchasing and Supply Management 18, 22-34.

Hayton, J.C., McEvoy, G.M., 2006. Competencies in practice: an interview with Hanneke C. Frese. Human Resource Management 45, 495-500.

Jones, R.G., Sanchez, J.I., Parameswaran, G., Phelpss, J., Shoptaugh, C., Williams, M., 2001. Selection or training? A two-fold test of the validity oj job analyticratings of trainability. Journal of Business and Psychology 15, 363-389.

Kamann, D.J.F., 2000. Matrices, cubes and triangles in purchasing. In: Proceedings of the 9th International IPSERA Conference, London, Canada.

Ketchen, D.J., Shook, C.L., 1996. The application of cluster analysis in strategic management research: an analysis and critique. Strategic management journal 17 (6), 441-458.

Killen, K., Kamauff, J., 1995. Managing Purchasing. Irwin Publishing, Homestead, IL.

Kolchin, M.G., Giunipero, L.C., 1993. Purchasing Education and Training: Requirements and Resources. Centre for Advanced Purchasing Studies, Tempe, Arizona.

Kraljic, P., 1983. Purchasing must become supply chain management. Harvard Business Review 61, 109-117.

Krishnaswamy, K.N., Sivakumar, A.L., Mathirajan, M., 2006. Management Research Methodology: Integration of Principles, Methods and Techniques. Pearson Education, Delhi.

Lamming, R., 1993. Beyond Partnership: Stategies for Innovation and Lean Supply. Prentice Hall, London.

Lee, J.W., Jones, P.S., Mineyama, Y., Zhang, X.E., 2002. Cultural differences in response to a Likert scale. Research in Nursing \& Health 25, 295-306.

Lilliecreutz, J., Ydreskog, L., 1999. Supplier classification as an enabler for a differentiated purchasing strategy. Global Purchasing \& Supply Chain Management 11, 66-74.
Long, C.S., Ismail, W.K.W., 2012. The HR specialist as an agent of change. Human Resource Management International Digest 20, 24-28.

Mulder, M., Wesselink, R., Bruijstens, H.J., 2005. Job profile research for the purchasing profession. International Journal of Training \& Development 9 (3), 185-204.

Murphy, E., 1995. Half the Battle is Knowing What Skills to Acquire. Purchasing, $119 ;$, pp. 49-54.

Nellore, R., Soderquist, K., 2000. Portfolio approaches to procurement - analysing the missing link to specifications. Long Range Planning 33, 245-267.

Olsen, R.F., Ellram, L.M., 1997. A portfolio approach to supplier relationships, Industrial Marketing Management 26, 101-113.

Padhi, S.S., Wagner, S.M., Aggarwal, V., 2012. Positioning of commodities using the Kraljic portfolio matrix. Journal of Purchasing and Supply Management 18, 1-8.

Pagell, M., Wu, Z.H., Wasserman, M.E., 2010. Thinking differently about purchasing portfolios: an assessment of sustainable sourcing. Journal of Supply Chain Management 46, 57-73.

Pearson, J.N., Gritzmacher, K.J., 1990. Integrating purchasing into strategic management. Long Range Planning 23, 91-99.

Pooley, J., Dunn, S.C., 1994. A longitudinal study of purchasing positions: 19601989. Journal of Business Logistics 15, 193-214.

Punj, G., Stewart, D.W., 1983. Cluster analysis in marketing research - review and suggestions for application. Journal of Marketing Research 20, 134-148.

Quintens, L., Pauwels, P., Matthyssens, P., 2006. Global purchasing strategy: conceptualization and measurement. Industrial Marketing Management 35, $881-891$.

Reinecke, N., Spiller, P., Ungerman, D., 2007. The talent factor in purchasing. McKinsey Quarterly 1, 6-9.

Ritter, T., 2000. A framework for analyzing interconnectedness of relationships. Industrial Marketing Management 29, 317-326.

Rozemeijer, F.A., van Weele, A., Weggeman, M., 2003. Creating corporate advantage through purchasing: toward a contingency model. Journal of Supply Chain Management 39 (1), 4-13.

Sanchez, J.I., Levine, E.L., 2009. What is (or should be) the difference between competency modelling and traditional job analysis? Human Resource Management Review 19, 53-63.

Shao, X.-F., 2011. Demand-side reactive strategies for supply disruptions in a multiple-product system. International Journal of Production Economics 136, 241-252.

Shub, A.N., Stonebraker, P.W., 2009. The human impact on supply chains: evaluating the importance of "soft" areas on integration and performance. Supply Chain Management - An International Journal 14, 31-40.

Stening, B.W., Everett, J.E., 1984. Response styles in a cross-cultural managerial study. Journal of Social Psychology 122 (2), 151-156.

Tassabehji, R., Moorhouse, A., 2008. The changing role of procurement: developing professional effectiveness. Journal of Purchasing Supply Management 14, 55-68.

Trautmann, G., Bals, L., Hartmann, E., 2009a. Global sourcing in integrated network structures: the case of hybrid purchasing organizations. Journal of International Management. 15, 194-208.

Trautmann, G., Turkulainen, V., Hartmann, E., Bals, L., 2009b. Integration in the global sourcing organization - an information processing perspective. Journal of Supply Chain Management 45, 57-74.

Tushman, M.L., Nadler, D.A., 1978. Information Processing as an Integrating Concept in Organizational Design. Academy of Management Review 3 (3), 613-624.

Weems, G.H., Onwuegbuzie, A.J., 2001. The impact of midpoint responses and reverse coding on survey data. Measurement and Evaluation in Counseling and Development 34, 166-176.

Zhang, C., Hu, Z., Gu, F.G., 2008. Intra- and interfirm coordination of export manufacturers: a cluster analysis of indigenous Chinese exporters. Journal of International Marketing 16 (3), 108-135.

Zheng, J., Knight, L., Harland, C., Humby, S., James, K., 2007. An analysis of research into the future of purchasing and supply management. Journal of Purchasing and Supply Management 13, 69-83. 